Anuario Latinoamericano Ciencias Políticas

y Relaciones Internacionales

vol. 6, 2018

pp. 235-261

\section{Política de defesa, segurança internacional e Forças Armadas Brasileiras no contexto sub-regional}

\section{Defense policy, international security and the Brazilian Armed Forces in the subregional context}

\author{
Cláudio de Carvalho Silveira \\ DEPARTAMENTO DE RELAÇÕES INTERNACIONAIS \\ INSTITUTO DE FILOSOFIA E CIÊNCIAS HUMANAS \\ UNIVERSIDADE DO ESTADO DO RIO DE JANEIRO \\ $\triangle$ ccsilv@yahoo.com \\ https://orcid.org/0000-0002-9578-7373
}

\title{
RESUMO
}

Este texto é uma abordagem de determinadas questões sobre segurança internacional e defesa na América Latina, enfatizando a inserção do Brasil no contexto sub-regional da América do Sul. Ele trata de temas sobre as bases de atuação das Forças Armadas brasileiras, num contexto de cooperação no período pós-ditatorial, durante os anos 1980 até 2016, com a queda do governo Dilma Rousseff. Neste sentido, o trabalho analisa algumas das principais questões do Estado, da política $e$ do contexto internacional ao fim do século XX e início do século XXI. Considerase aqui a necessidade de articulação entre a política externa e as características da política de defesa brasileira, os interesses nacionais, a realidade hemisférica, a modernização da capacidade militar e os princípios de cooperação com os países sul-americanos. Estes temas são aqui pensados dentro de um quadro de criação de objetivos e mecanismos de cooperação, como a segurança coletiva e cooperativa e a importância de instituições como o MERCOSUL e a UNASUL.

PALAVRAS-CHAVE: Brasil, América Latina, política externa e política de defesa, forças armadas, cooperação sub-regional, segurança coletiva e cooperativa, democracia.

\section{ABSTRACT}

This text is an approach to some questions on international security and defense in Latin America, emphasizing the insertion of Brazil in the sub-regional context of South America. It deals with topics related to the Brazilian Armed Forces in the context of cooperation in the post-dictatorial period, that is from 1980 to 2016, when the Dilma Rousseff's government fell. In this sense, the paper analyzes some of the main issues of the State, politics and the international context at the end of the 20th 
century and the beginning of the 21st century. The author dwells on the need of articulation between the Brazilian foreign policy and defense policy, the national interests, the hemispheric reality, the modernization of the military capacity and the principles of cooperation with the South American countries. These issues are thought within a framework of goal-setting theory and mechanisms of cooperation, such as collective and cooperative security, and the importance of institutions such as MERCOSUR and UNASUR.

KEYWORDS: Brazil, Latin America, foreign policy and defense policy, armed forces, sub-regional cooperation, collective and cooperative security, democracy.

\section{Introdução}

Este artigo refere-se à pesquisa do autor desenvolvida na área de defesa, segurança internacional e forças armadas na América Latina, privilegiando o Brasil e a sua inserção sub-regional desde o fim da transição das ditaduras à democracia até o período dos governos chamados progressistas ou desenvolvimentistas, de postura contrária ao neoliberalismo, que se estabeleceram na América do Sul. No contexto brasileiro, isto se estabeleceu, com algumas exceções, desde o início do século XXI até 2016, com o golpe de Estado que tirou Dilma Rousseff da presidência do país (Freixo, Rodrigues 2016). A primeira versão deste texto foi apresentada no IX Congresso Latino-americano de Ciência Política, em julho de 2017, na cidade de Montevidéu. Agradecemos os valorosos comentários dos colegas da área da política internacional, relações internacionais, política exterior e integração regional presentes neste evento. Inicialmente, aludimos à abordagem temática que sustenta a proposta voltada para a fundamentação teórica da mesma, onde se levantam problemas clássicos e atuais sobre o Estado e a aplicação das Forças Armadas (FFAA) sulamericanas ao longo do tempo, de acordo com a elaboração de um dado conjunto de analistas que abordaram o tema no âmbito da política internacional. Para tal, levamos em conta aspectos que estão voltados para os fundamentos da soberania, da guerra, do direito internacional, da interdependência estatal, da defesa nacional e das relações internacionais e como tais questões podem ser pensadas para compreender a inserção do Brasil no cenário mundial. Em seguida, justificamos tais aspectos tomando como base a realidade brasileira diante da relação entre política de defesa e política externa na convivência de nosso país a nível sub-regional, hemisférico e mundial em nome dos chamados "interesses nacionais", ainda que estes sejam de difícil definição na complexidade do mundo contemporâneo. Aqui consideramos os temas sobre as instituições nacionais, bilaterais e multilaterais que têm criado um clima de maior ou menor rivalidade ao longo da nossa história, confrontação e cooperação. Trata-se, então, dos fundamentos do emprego político do poder militar em consonância com os objetivos e características da política tradicionalmente 
desenvolvida pelo país no cenário internacional. Para isto, tem se promovido um processo de modernização ético-política e técnico-operacional que visa de obter capacidades estratégicas por meio de uma estrutura organizacional que se utiliza de meios bélicos para executar suas funções de maneira considerada adequada para dissuadir o oponente. É sabido que os Estados-nação, ao serem constituídos na Europa da Era Moderna se organizaram e se expandiram para além das suas fronteiras territoriais, para outros continentes graças à participação fundamental de exércitos e das marinhas, de soldados, armas, canhões, cavalos, batalhões, marinheiros, barcos mercantis e vasos de guerra, representando, assim, a importante presença do poder militar. Apesar de tais instituições serem atualmente questionadas, em nome da cooperação e integração regional, da globalização, etc., elas não deixam de ter relevância para discutir sobre o comportamento dos países na realidade latino-americana e demais regiões do mundo.

Neste sentido, nossa questão se refere a tentar saber se há e qual é o entendimento predominante no Brasil sobre os vínculos entre defesa, cooperação e modernização das suas FFAA sem abrir mão de seus interesses de projeção de poder na América do Sul. Apesar de sua arquitetura institucional como o Mercado Comum do Sul (MERCOSUL) em 1991 e a União das Nações SulAmericanas (UNASUL) em 2008, continuou a desenvolver projetos no setor militar para atender interesses nacionais próprios e atender sua capacidade dissuasória.

O texto está organizado em três partes. Na primeira, há uma breve alusão à importância do poder militar para os interesses dos Estados, onde destacamos a perspectiva realista para entender se ela pode ser aplicada à situação brasileira, no contexto internacional onde está inserido. Na segunda parte, consideramos o tema da modernização militar a partir das possibilidades da cooperação do Brasil com seus vizinhos, em especial a Argentina, para estabelecer uma fase de maior proximidade, contribuindo para criar algum tipode comunidade de segurança coletiva e / ou cooperativa. Na terceira parte, abordamos porquê e como o Brasil mantem sua estrutura de defesa no período democrático até meados do ano de 2016 e encaminha a sua modernização organizacional e técnico-operacional, abrindo mão do uso do termo segurança cooperativa, mas, primando pelos esforços de cooperação na sub-região.

\section{O poder militar e sua função no mundo atual}

Nesta parte inicial, perguntamos por que, segundo o neorrealismo, os Estados nacionais utilizaram seus recursos para mobilizar o poderio militar à luz das suas características apresentadas na literatura acadêmica, como em K. Waltz (1959). Tais características são importantes para elucidar a peculiaridade deste tipo de organização social e política, seu triunfo e sua permanência, apesar de enfrentar crises e riscos dentro de um sistema internacional que se
Política de defesa, segurança internacional e Forças Armadas Brasileiras no contexto sub-regional

Cláudio de Carvalho Silveira 
tornou cada vez mais interligado e interdependente. Como se sabe, o sistema de Estados funcionou com a necessidade de manter a soberania, centralização administrativa, autonomia de poder e territorialidade. Para que fossem concretizados efetivamente, foi necessária a presença do poder militar como a forma de utilização do monopólio do uso legítimo da violência, no exercício da autoridade política dentro e fora de suas fronteiras. Neste caso, a formação de um aparato bélico foi e continua a ser importante, já que a guerra tem sido um elemento essencial para a formação e a relação dos Estados uns com os outros, construindo consensos e administrando os conflitos com base nos seus interesses, conforme veremos a seguir. Ao longo do tempo, a análise histórica demonstrou que nas guerras travadas e na manutenção da paz esses interesses podem se harmonizar ou entrar em conflito, como nas grandes guerras do século XX e no período da manutenção da Guerra Fria. Por isso, lembramos aqui da discussão elaborada por Waltz acerca das causas da guerra e sua relação com a posição adotada pelos Estados no cenário internacional. Fundamentando suas reflexões sobre a condição humana e a constituição dos Estados no mundo moderno, este autor utiliza a contribuição do pensamento clássico e contemporâneo ao construir três imagens que possuem capacidade explicativa para a origem da guerra e dos conflitos entre os Estados. Tratar da razão de ser da guerra é tratar também do seu fim, isto significa procurar entender como é possível estabelecer a paz. Assim, segundo Waltz, temos as seguintes possibilidades de eclosão de guerras: a) a essência maligna do homem; b) o peso da estrutura social interna na política externa e c) a busca dos interesses pelo equilíbrio de poder no cenário internacional, considerando a ação diplomática e o uso da força.

Concordamos com este autor sobre a maior força explicativa da terceira imagem, porque ela trabalha com um senso mais próximo da realidade da política internacional. Decerto, a bondade e a maldade do ser humano são aspectos a serem considerados, como é admitido também no caso do pensamento socialista: o processo de exploração de uns sobre outros, que exacerba e aprofunda os conflitos. Isto significa dizer que a moralidade e a dominação por si só não são capazes de dar conta de toda a situação da relação entre os Estados porque os seus interesses e a perseguição de seus objetivos é bastante patente nas relações internacionais, conforme demonstra o processo histórico moderno e contemporâneo. Ainda que todos os homens e seus Estados sejam bons e trabalhem cooperativamente, haverá alguns assuntos onde os interesses serão distintos. Portanto, entendemos que, enquanto houver entidades conhecidas como Estados-nação, portadoras de um considerável grau de autonomia, soberania, criando leis, regras, mantendo armas, administrando recursos e formulando objetivos, tanto a iminência de conflitos e guerras como o arranjo pacífico e cooperativo, estarão presentes na ordem do dia. Assim, a guerra, ou a paz, podem ser entendidas como situações circunstanciais no jogo de poder estabelecido pelos Estados-nação, pois, o que importa em suas relações é a busca do exercício da "política de poder" para alcançar os seus objetivos. A negociação política 
é admitida de modo pacífico ou belicoso, onde o uso da força, se necessário, é igualmente levado em conta. Houve diversas transformações históricas que criaram implicações sobre a soberania estatal e as relações internacionais sobre o poder militar na guerra e na paz. Por exemplo, elas podem ser encontradas nas análises de Mann (1992) Tilly (1996) e Giddens (2001). Entretanto, vale dizer, para estes e outros autores, o que pode ser válido para a realidade de grandes potências, não é necessariamente capaz de explicar a condição de potência de porte médio e periférico como o Brasil, no seu intuito de ajudar e promover a cooperação Sul-Sul, conforme veremos em seguida.

\section{O Brasil e a sua inserção internacional a partir dos anos 1980}

O que nos parece importante dentro desse quadro de problematização teórica, é perceber a ação do Brasil como um país do Terceiro-Mundo, tido como cooperativo e pacífico no âmbito do sistema internacional. Este país e seus vizinhos da América Latina, notadamente os sul-americanos, chegaram a alcançar uma posição bastante diferente dos padrões existentes nas outras regiões do mundo, cujos Estados foram forjados através das guerras ocorridas ao longo do tempo (Rouquié 1984). Para este autor, enquanto em várias regiões periféricas, um processo de militarização que foi seguidamente aumentado, colaborando com a eclosão de conflitos nacionalistas, regionais e com intervenções políticas internas, nos países latino-americanos, tal tipo de militarização foi diminuindo ao longo das últimas décadas. Por um lado, isto ocorreu apesar de algumas crises históricas terem acontecido nos subcontinentes centro-americano e sul-americano. Por outro lado, permitiu a busca de uma situação mais adequada para o avanço das relações cívico-militares e da democracia, por exemplo: o caso do Brasil pós-ditatorial e o da Argentina, a partir da transição democrática realizada depois da crise das Malvinas. A partir deste contexto e ambos os países, pensou-se ser possível o estabelecimento de um pensamento político-estratégico que contribuísse para consolidar a preponderância do poder civil sobre os militares e fazer valer os princípios básicos de sua utilização para a defesa nacional, a democracia e a cooperação regional. Isto deveria ser capaz de contribuir para manter os soldados afastados da cena política interna, mesmo considerando a contenção de seu alto grau de autonomia e força política existentes em nossa história. Tal posicionamento levaria as FFAA a se voltarem mais para o acompanhamento da situação internacional, o que nos parece ser o mais adequado, segundo o que já preconizamos ao analisar o caso da formação militar-naval na Marinha do Brasil (MB) (Silveira 2016). Como outros países, não se pode negar que o Brasil possui interesses, que são, genericamente, relacionados aos de sua elite ou aos das elites dos países mais ricos. Assim, é válido dizer também que, mesmo com sérias restrições à sua capacidade de atuação no cenário mundial, o país buscou se apresentar com um razoável desempenho na sua busca
Política de defesa, segurança internacional e Forças Armadas Brasileiras no contexto sub-regional

Cláudio de Carvalho Silveira 
pela liderança dos países do subcontinente e de válido negociador das crises que afetam o relacionamento Norte-Sul nas últimas décadas. Baseado nisso, o Ministério das Relações Exteriores (MRE) e o Ministério da Defesa (MD), apesar das diferenças e disputas burocráticas internas, trabalharam com o intuito de executar a política externa, no âmbito da diplomacia e da defesa, participando de diversos organismos multilaterais sem, contudo, descuidar da emergência de algum conflito armado ou de uma guerra sendo a consideração de cenários e ameaças possíveis (Alsina Jr 2009). Tal entendimento fez com que as FFAA brasileiras pudessem estar organizadas e preparadas para garantir os interesses nacionais dentro e fora do território nacional, adequando a elaboração de um pensamento político-estratégico que justificasse esse tipo de atuação na comunidade internacional, num mundo cada vez mais interdependente na guerra ou na paz (Keohane 1992). Um bom exemplo da conjugação da ação diplomática e militar em tempos de paz passasse a ser a presença brasileira em algumas "missões de paz" da ONU, na África, na Europa e na Oceania. Além de mobilizar efetivos e equipamentos isto ajudou a confirmar o estatuto de "país pacífico" e legitima os esforços da chancelaria em perseguir o alvo da política externa que visa aumentar a presença internacional brasileira.

Neste sentido, para que o Brasil tivesse uma política externa capaz de fazer valer seus interesses soberanos diante dos outros Estados, o país precisaria dispor de meios adequados para o uso da força, conforme o sentido da terceira imagem de Waltz. Ainda que a tradição diplomática brasileira, construída desde o século XIX, tenha sido de procurar ao máximo a resolução pacífica dos conflitos, não se pode prescindir da preparação no campo militar. Daí, a projeção do país dentro e fora do continente não dependeria apenas do seu "poder brando" mas, também, do seu "poder duro" (Nye 1990) juntamente com a elaboração do planejamento do preparo e do emprego das FFAA, apesar da América Latina ser considerada uma da áreas menos militarizadas do Mundo. Uma vez definidos, tais interesses nacionais, eles poderiam ser garantidos através da negociação ou da força, mas, o problema inicial é demarcar quais são esses interesses sem cair no abismo da discussão ideológica, pois, eles são de difícil definição, conforme Lima (2010). Mesmo com esta dificuldade, segundo esta autora, genericamente, tais interesses podem ser enumerados da seguinte forma: a) a defesa das fronteiras; b) a defesa do "status quo" no sistema regional; c) defesa das rotas e da participação no comércio internacional e na aquisição de tecnologia; d) defesa dos interesses nacionais em outros Estados.

Por isso, tendo como alvo imediato a América do Sul, o Brasil procurou estabelecer e viabilizar certa interdependência nos planos da cooperação e da integração nos mecanismos recém-criados de abrangência sub-regional. Este é o caso da UNASUL e, especialmente, do seu conselho de defesa, o CDS, criado a partir de 2008, como um órgão consultivo para tratar dos problemas relacionados a este tema na sub-região.

Ao mesmo tempo, o país não abre mão de soberania e da possibilidade de agir por conta própria, pois, no pensamento estratégico brasileiro a ênfase 
tem sido dada na dissuasão do inimigo, conforme está explicitado nos documentos que tratam do assunto. Estes documentos buscam manter certa unidade quanto ao discurso e ressaltam o uso da força só em último caso, uma vez esgotadas todas as possibilidades de negociação intermediada por outros Estados e pelos órgãos do Direito Internacional. Em suas denominações mais recentes, os documentos mais importantes são denominados de: Estratégia Nacional de Defesa (END) de 2008, revisada em 2012, Política Nacional de Defesa (PND) de1996, rebatizada de Política Nacional de Defesa em 2005 e revisada em 2012 e Livro Branco de Defesa Nacional (LBDN) de 2012. É bom esclarecer que outra versão provisória da PND e END passou a ser discutida a partir de 2016, mas, ainda carece de aprovação final dos poderes do Estado, portanto, a menção de sua índole foge ao escopo deste texto. Tal como expressos naqueles documentos, no plano político-militar, a dissuasão é entendida como a capacidade de defesa bem como a resistência à agressão externa e como a capacidade de pronta resposta ao eventual agressor, de passar da ameaça ao emprego militar, explorando as vulnerabilidades do adversário.

Contudo, não podemos deixar de lembrar que a introdução de elementos complicadores no contexto mundial aumentou a complexidade da lógica de funcionamento das decisões político-estratégicas e foram agregados novos dimensionamentos conflitos e estruturas de poder. Este é o caso das novas tecnologias, a globalização, o aumento da desigualdade e da discriminação, causando um preocupante estado de caos que reconfigura o pensamento geopolítico (Ramonet 1997). O entorno estratégico foi também afetado por uma necessidade de reposicionamento das análises de emprego da força e apresenta novos desafios para o entendimento da segurança internacional do mundo pósGuerra Fria (Bartolomé 1999). Por isso, passou a ser significativo considerar a modernização das FFAA na situação sul-americana e a atitude que seus países têm tido a partir do passado recente de instituição de ditaduras e democratizações ocorridas no subcontinente. Assim, pode-se avaliar em que medida teste processo se dá, a fim de contribuir com a estabilidade, a paz e cooperação e medidas de confiança mútua. Este foi o caminho viável para justificar o uso da força dentro de um quadro de possível conformação de um complexo regional de segurança que evita guerras, conflitos e crises entre seus membros, onde, mesmo considerando aspectos do realismo, admite-se possibilidades de construção de novas perspectivas e arranjos político-estratégicos conforme Buzan, Weaver, De Wilde (1998). Esta postura teórica é importante para nós, sobretudo numa situação onde os aspectos de segurança e defesa internacional podem ser pensados não apenas centrados no setor militar, mas enquadrados também numa abrangência mais ampla, com diferentes níveis e presença de outros atores no contexto internacional, além dos estados. Neste sentido, também Diamint (2001) considerou que, por causa da argumentação crítica desses autores de Copenhague, no contexto latino e sul-americano, o neorrealismo possui limitações ao explicar o movimento de tentativas de integração e cooperação. Alguns aspectos relacionados ao neoinstitucionalismo
Política de defesa, segurança internacional e Forças Armadas Brasileiras no contexto sub-regional

Cláudio de Carvalho Silveira 
também devem ser levados em conta nesta situação, abrindo espaço para a funcionalidade das organizações internacionais que possuem um papel importante ao buscar espaços de interação, padronização e criação de políticas mais convergentes na região.

Por considerarmos este debate relevante, é necessário fazer um questionamento de se, e em que medida, uma potência mediana como o Brasil, teria condição para exercer uma política de projeção de poder e liderança. Ao mesmo tempo, deve-se admitir se este país poderia ajudar a promover um tipo de segurança cooperativa na América do Sul com a participação de seus vizinhos, sem abrir mão dos interesses nacionais, tal qual é a perspectiva argentina, com quem teve disputa de influência ao longo da história (Ministerio de Defensa Argentino 2014) e, também, como outrora se expressou, o Uruguai (Ministerio de Defensa 2005).

Conforme veremos a seguir, percebemos que o Brasil tem recusado o uso do termo "segurança cooperativa" porque não quer se enquadrar num marco conceitual onde teria que abrir mão de algumas doutrina e práticas que poderiam reduzir a sua autonomia no entorno estratégico. Se assim fosse, oficialmente, o país entende que poderia cair no risco de ter que se submeter a um modelo de estrutura defensiva, dentro do enquadramento da segurança hemisférica estabelecida pelos Estados Unidos da América (EUA), onde se tornaria difícil manter o objetivo de projetar poder e modernizar as suas FFAA de acordo com seus interesses nacionais e suas pretensões de liderar o subcontinente sul-americano.

\section{Confrontação e cooperação regional: antecedentes históricos}

Nesta segunda parte, abordamos a questão da cooperação no contexto sulamericano. Aqui destacamos que, no passado recente, a tentativa de construir um hipotético país potência teve seus reflexos no grau de investimento e na formulação de teorias / guias de atuação dos governos da sub-região, tendo interferência na forma que estes se comportaram. Por exemplo, a criação da teoria de "fronteiras vivas", formulada por Teixeira Soares (1972), sugeriu a insatisfação brasileira com suas fronteiras e abriu a possibilidade de revisão destas para a obtenção de objetivos estratégicos, assim como as propostas elaboradas por Golbery de Couto e Silva (1981). Tais formulações colocaram o Brasil, na ótica dos demais países sul-americanos, numa posição de inimigo potencial por causa dos temores que se tornassem sub-imperialistas em relação aos seus vizinhos. Não é de se espantar que tais ideias ajudaram no contexto de insegurança e de conflito que se desenvolvia, onde as perspectivas de integração e cooperação eram, no mínimo, desanimadoras nos anos 1960 até os anos 1980, durante o autoritarismo civil-militar brasileiro, instaurado em 1964, com o golpe efetuado, que resultou nos governos militares estabelecidos até 1985, findos com um presidente eleito indiretamente. 


\section{Democratização e cooperação na América do Sul}

Com o fim do período autoritário, no final da década de 1980 e início da década de 1990, os países sul-americanos começaram a trabalhar em uma dinâmica distinta. O fim da Guerra Fria, no contexto internacional, e as inúmeras dificuldades econômicas vividas pelos países, no contexto regional, apresentaram a estes um novo sistema internacional no qual teriam de se relacionar. Em termos mais claros, a queda dos governos militares, a democratização dos países na América do Sul, a revisão das políticas econômicas e o regionalismo foram elementos que provocaram grandes modificações na condição da política externa e interna nos respectivos países. Na América do Sul uma das modificações foi o fim das rivalidades existentes até o período anterior, especialmente, nas relações entre Argentina e Brasil, como abordaram SaintPierre, Winand e Pereira (2007).

Com a introdução de políticas neoliberais, por meio de cortes no orçamento, Brasil e Argentina viram suas estruturas militares serem diminuídas ao longo das últimas décadas do século XX. Outros países sul-americanos também estavam inseridos nesta lógica de desmonte, como a Venezuela e o Equador pré-bolivarianismo. Além daqueles países que historicamente já mantinham níveis baixos de investimento militar, outros ainda acabaram por serem atingidos pela ideia de redefinição do papel das FFAA. Isto significa dizer que, se antes as elas atuariam exclusivamente na defesa da nação contra o inimigo externo, com a redefinição, os militares teriam papel interno na defesa da ordem institucional. Assim, apesar de tudo, na maioria dos países sulamericanos as FFAA destes países sofreram um processo de desvalorização causado pelo ajuste das contas internas, que cortou os investimentos na área, havendo adaptação do seu papel, sem deixar de resguardar o Estado contra o inimigo externo para combater problemas internos, como o narcotráfico.

Nos anos 1990 houve ainda eleição de governos civis temerosos da possibilidade de eclosão de novos golpes, o que fez com que as FFAA fossem diminuídas enquanto agentes nacionais. Além do que, houve o surgimento de suposições sobre a falta de funcionalidade efetiva dos militares num conflito internacional, tendo como base a crise das Malvinas em 1982. Neste contexto, prevaleceu a supervalorização dos elementos econômicos que legitimariam cortes na defesa e também o receio de que FFAA fortalecidas poderiam voltar a intervir na política interna, como no passado, o que se conhece pelo nome de "revanchismo".

Apesar destes problemas, a cooperação brasileira com os países sul-americanos continuou existindo com atividades variadas. No âmbito estritamente militar, se destacaram medidas como a "Operação Cruzeiro do Sul", realizada conjuntamente pelas FFAA dos países em 1996, os exercícios navais "Fraterno", também ocorridos em 1996, "Operação Laço Forte" de 2001, a criação do "Memorando de Entendimento sobre Consultas e Coordenação" de 1997. Segundo a ótica do governo brasileiro, a cooperação estratégica, foi pensada como uma
Política de defesa, segurança internacional e Forças Armadas Brasileiras no contexto sub-regional

Cláudio de Carvalho Silveira 
forma de atenuar os ataques das grandes potências aos países da região, além de permitir outros benefícios para os países envolvidos. Por exemplo, uma aproximação entre Brasil e Argentina podia ser benéfica para ambos, porque estes estavam sujeitos aos mesmos desequilíbrios do sistema internacional, não fazia mais sentido se encararem como inimigos, ou rivais. Antes de tudo, os dois países deviam atuar de forma coordenada para suavizar os efeitos das medidas internacionais nas suas fronteiras, especialmente na área econômica.

Como afirmado antes, outro fator fundamental para o aumento da cooperação política dos países da região foi o elemento democrático, no sentido de retirar os militares e a sua "lógica" da vida política nacional. Nesse momento de maior aproximação entre Brasil e Argentina foi assinada a "Ata para a Integração Brasileiro-Argentina e seus Protocolos 1 a 12", "Declaração Conjunta sobre Política Nuclear" e "Ata de Amizade Brasileiro-Argentina”, todos de 1986; "Declaração Conjunta sobre Política Nuclear", de 1987. Além disso, deve-se ressaltar a assinatura do TNP (Tratado de Não-Proliferação Nuclear) pelo Brasil e a Argentina.

Neste período, há de se destacar que alguns governos brasileiros foram mais propensos a reformar as FFAA e cooperar regionalmente do que outros, mas não é exagero afirmar que a região segue um padrão semelhante neste período. No Brasil, quando ainda existia uma forte participação dos militares no governo Sarney, tais atos podem ser considerados como tímidos se comparados com os da década seguinte. O que tornou o modelo cooperativo entre Brasil-Argentina mais assertivo na década de 1990 foi o ajuste fiscal, com o desmantelamento por Fernando Collor de Mello de uma série de projetos governamentais, inclusive, os militares. Além disso, pôs em termos mais rígidos a suposta subordinação das FFAA aos civis. O avanço da cooperação seguiu outros níveis entre os países é evidente neste período. Os Estados da região se aproximaram e formaram o bloco econômico do MERCOSUL, como Brasil, Argentina, Uruguai, Paraguai, mais tarde a Venezuela. Alguns deles também firmaram tratados importantes como o Tratado de Cooperação Amazônica (TCA). Este tratado foi uma tentativa de aproximação brasileira dos países amazônicos, Bolívia, Colômbia, Equador, Guiana, Peru, Venezuela e Suriname. Houve também a Declaração de Iguaçu em 1990, a Declaração de Mendoza, proibindo armas químicas e biológicas, a criação do Grupo do Rio. Em 2002 foi elaborado o "Consenso de Guayaquil sobre Integração, Segurança e infraestrutura para o Desenvolvimento" e, ainda o aprofundamento da Zona de Paz da América do Sul.

É consenso que o MERCOSUL, criado pelo Tratado de Assunção em 1991, foi fruto da aproximação entre Brasil e Argentina iniciada na década de 1980. As negociações tomaram contorno mais visível nos governos Sarney e Alfonsín que, em 1985 e 1986, assinaram a Declaração de Iguaçu e a Ata para a Integração Argentino-Brasileira, respectivamente. Em 1990 foi assinada a Ata de Buenos Aires, que previa uma antecipação do prazo para a formação da união aduaneira para 1994. Em 1995 foi o ano em que 
o MERCOSUL passou a existir efetivamente no formato de uma união aduaneira. Segundo Bandeira (2009a) a integração entre Brasil e Argentina, no qual as negociações começaram já no ano de 1985, mas que só foi formalizado em 1991, tinha um objetivo muito mais amplo do que simplesmente o aumento do fluxo do comércio regional e muito mais extenso do que apenas o Cone Sul. O MERCOSUL foi instituído como uma lógica estratégica, tendo o Brasil e a Argentina como centro de gravidade. Isto fez com que, por mais que o objetivo do MERCOSUL tenha sido distorcido, o governo brasileiro tentou durante toda a década seguinte dar continuidade a este objetivo estratégico (Cervo 2008).

No plano estratégico-militar, o clima dos anos 1980-1990 demonstrou que a Guerra das Malvinas, representou uma nova realidade por causa da agressão de uma potência de primeira grandeza ao antigo rival e parceiro das pretensões terceiro-mundistas do Brasil. Ficou claro que o continente americano apresentava uma vulnerabilidade estratégica, pois nem mesmo a estrutura de cooperação militar formado pelo Tratado Interamericano de Assistência Recíproca (TIAR) em nome da: a) identificação dos EUA com a Inglaterra a partir de laços histórico-culturais; b) participação destes países na associação político-militar do Atlântico Norte; c) manutenção da ordem internacional calcada no "pentagrama" de Kissinger; d) assimetria das relações Norte-Sul. Tal como a terceira imagem de Waltz, no conflito das Malvinas, a Argentina foi um exemplo de como uma potência de mediana categoria, apresentou uma série de dificuldades para impor os seus objetivos mesmo quando recorreu ao uso da força. Isto reforçou no Brasil e nos outros parceiros a visão sobre os riscos de adotar uma posição mais agressiva e alertou para as debilidades encontradas quando houver uma situação na qual o princípio da dissuasão for posto em prática (Vidigal 1996).

A Argentina que foi vista como a principal rival do Brasil no subcontinente - razão pela qual as principais hipóteses de conflito estavam concentradas nas fronteiras do Sul - passou a ser vista como parceira privilegiada e coadjutora da estabilidade. Isto aconteceu no mesmo momento em que foi feita a opção pelo fim da competição nuclear entre os dois países e a disposição de chegar à dupla adesão aos termos do Tratado de Não-Proliferação Nuclear (TNP). $\mathrm{O}$ esforço da diplomacia concentrou-se em criar condições para o aperfeiçoamento da cooperação entre ambos, contando ainda com a presença de outros parceiros, o que resultou nas bases da criação do MERCOSUL como associação econômica e, mais tarde, da UNASUL, como instituição eminentemente política. Com esta mudança a componente militar ficou em segundo plano, mesmo mantendo o princípio da dissuasão. Isto aconteceu num contexto em que permaneceram as assimetrias entre os países do bloco, e, destes, com os países desenvolvidos. Além do que, houve os riscos que envolveram as atitudes dos maiores países, Brasil e Argentina, de manterem disputas, bem como as razões dos países sul-americanos para constituírem um complexo regional de segurança. Por fim, houve um razoável consenso de que deveriam
Política de defesa, segurança internacional e Forças Armadas Brasileiras no contexto sub-regional

Cláudio de Carvalho Silveira 
buscar a integração regional de forma cautelosa e empreender esforços para superar dificuldades históricas (Tulchi, Bitencourt 2005).

Outra atitude importante foi a Iniciativa Amazônica, lançada em 1992 pelo governo de Itamar Franco, foi uma tentativa de aproximar o eixo do MERCOSUL dos países da Comunidade Andina de Nações. Na ocasião foi elaborado um entendimento para se criar uma área de livre-comércio sul-americana, a Área de Livre Comércio da América do Sul (ALCSA), em dez anos, que não logrou êxito. Como nas negociações para a criação do MERCOSUL, o entendimento era de que a ALCSA deveria ter um alcance não só comercial, mas também político, energético, estratégico e permitir a integração física dos países. Nos governos de Fernando Henrique Cardoso (1995 - 2003) a iniciativa pareceu ter sido deixada de lado, sendo negociados apenas acordos de livrecomércio em separado. Contudo, no ano 2000, Cardoso realizou um encontro entre os presidentes da América do Sul que, significou uma retomada na perspectiva da cooperação regional, numa tentativa de superar a integração subregional envolvendo MERCOSUL e Comunidade Andina de Nações (CAN).

Neste período, a viabilidade da estratégia dissuasória brasileira necessitaria também da modernização do equipamento e do aperfeiçoamento dos efetivos, desenvolvendo as suas num nível mais alto de profissionalização. Porém, um país cuja política externa se pauta pela busca da negociação e busca do consenso possível, poderia acabar por obscurecer a legitimidade do aumento dos gastos para com a defesa. A difusão do mito de que o Brasil é um país pacífico, e o será eternamente, dada a índole do seu povo, reforça a falta desse empreendimento. Isto resultou que a preocupação com a defesa nacional, ao invés de ser geral e com intensa participação da sociedade na escolha de suas prioridades, poderia ser vista por muitos como preocupação restrita aos chamados de belicosos e equivocados, que ainda pensam ser a força o principal instrumento para garantir interesses ou a solução para a resolução de impasses. Se no passado, a preocupação do país com a "Segurança Nacional" estava intimamente relacionada com a ditadura, a Guerra Fria etc, parece que hoje tem força na Chancelaria, no MD e em parte na opinião pública nacional a ideia do abandono do mito do "berço esplêndido", por causa da ação no crescente espaço dos regimes internacionais, da "globalização" de conflitos. Baseado nisso, houve a necessidade das instituições sociais e governamentais de discutir criticamente possíveis doutrinas de emprego estratégico das FFAA e a inserção do país na ordem internacional.

Desta maneira, a elaboração da PDN, em 1996, e a criação do MD em 1999, implicaram em repensar a cultura das Forças Singulares, o seu emprego estratégico e levanta uma questão importante: a valorização do poder civil. Isto reforçou a ideia de que tanto a diplomacia quanto o uso da força armada seriam considerados em cada circunstância sem endossar necessariamente qualquer tipo das históricas rivalidades entre os diplomatas e os militares (Gonçalves, Miyamoto 1995). Ambos passaram a ser considerados somente instrumentos do Estado soberano, conduzido pelo poder político e respaldado com a par- 
ticipação da sociedade, que tornaria possível à medida que se efetivasse um projeto político e econômico para o país capaz de contemplar a preparação de condições para o regate da dívida social (Dreifuss 1993).

\section{Segurança e modernização militar brasileira nos governos Lula da Silva e Dilma Rousseff}

Nesta terceira parte, perguntamos qual seria o propósito da modernização brasileira em relação ao intuito de cooperar com seus vizinhos e ao mesmo tempo reforçar a expectativa de exercer liderança sub-regional, visto que tem se apresentado de forma hesitante e falha na responsabilidade de assumir determinadas posições? Isto deveria incorporar ou não o conceito de segurança cooperativa em seus documentos oficiais, conforme em alguns de seus vizinhos da Bacia do Prata?

Aqui devemos lembrar que alguns dos temas da discussão sobre a segurança cooperativa já estavam embutidos no debate com os EUA sobre a questão hemisférica pós-Guerra Fria, por exemplo, nas exposições de Santa Fé conforme o relato de Schultz (1999). Isto implicou em pensar sobre as novas missões, preparo para as FFAA no contexto das chamadas novas amaças repercutindo em diferentes consequências nos países da América Latina e reforçou a hegemonia da superpotência do Norte. Segundo Lora (2010), no plano conceitual, a segurança cooperativa visa agir de maneira preventiva e combinada para evitar ou dirimir os conflitos num determinado concerto internacional. Ela se difere em parte da segurança coletiva, pois esta age como consequência da eclosão de uma ameaça ou conflito. Embora abarque a segurança coletiva, a segurança cooperativa procura ir além, agindo como suporte analítico de planejar e integrar as ações dos países numa dada região. O debate no nível hemisférico se desenvolveu junto com a adoção do conceito de multidimensionalidade da segurança e reunião da Organização dos Estados Americanos (OEA) de 2003, que serve a muitas significações, inclusive, a uma significação de segurança cooperativa. A partir daí, esta se prestou a ser mais apresentada segundo a lógica estadunidense, imposta ou apresentada como reação à mesma, e alimentou algo das iniciativas de cooperação Sul-Sul no contexto sub-regional.

A segurança cooperativa tem sido um horizonte a ser alcançado na manifestação oficial de alguns países, como Argentina e Uruguai, mas, não no caso do Brasil. Na análise dos documentos da defesa, a Argentina foi considerada mais explícita que o Brasil ao preconizar uma arquitetura regional baseada nos princípios da segurança cooperativa. Como mencionamos antes, nosso país não adota este conceito, sendo-lhe reticente, embora se diga aberto à cooperação na América do Sul (Soares 2012). Assim, podemos ressaltar que esta não é uma meta efetiva dos documentos brasileiros (PDN, END 2012), LBDN (2012). Entretanto, talvez ela ainda possa vir a se tornar uma realidade
Política de defesa, segurança internacional e Forças Armadas Brasileiras no contexto sub-regional

Cláudio de Carvalho Silveira 
entre nós, dependendo de como venham se desenvolver os diversos mecanismos e organizações regionais e sub-regionais ao longo das próximas décadas, podendo vir ou não a se tornar um curso sem retrocessos na configuração de um complexo regional de segurança (Fuccille 2015). Neste sentido, nosso entendimento é o de que, sem a pretensa conotação inicialmente estabelecida pelos interesses hegemônicos da superpotência estadunidense, a segurança cooperativa pode ser reinterpretada de modo a dinamizar e fortalecer a implementação e o desenvolvimento do CDS-UNASUL. Isto significa dizer que a adoção deste conceito permitiria maior integração e efetiva capacidade dos países cooperarem entre si, inclusive, contra as ameaças vindas desta, de outra grande potência, daquelas de menor porte.

\section{Perspectivas sobre a estrutura de defesa e postura sub-regional brasileira}

Em vista do exposto acima, consideramos tal argumento da segurança cooperativa, com o estudo das políticas de defesa, segurança internacional e das FFAA, apreciando, especificamente, o perfil estratégico brasileiro, construído historicamente. Para nossa análise é importante levarmos em conta o entorno regional, o mundial e as diretrizes adotadas pelo Brasil para responder a tal situação, conforme vermos a seguir. Ao abordar estes temas, destacaremos algumas razões, fundamentadas em conversas informais com autoridades e nos debates acadêmicos com civis e militares, realizados, sobretudo, no âmbito das atividades da Associação Brasileira de Estudos de Defesa (ABED). Então, percebemos que a negativa do Brasil em adotar o conceito de segurança cooperativa, pode ser explicada pelas razões enumeradas adiante, dentre outras possíveis de serem mencionadas.

A primeira razão a ser justificada, é a importância do contexto sub-regional, onde a posição do Brasil sofreu algumas modificações importantes no passado recente, depois do advento das recentes mudanças no plano políticoestratégico mundial. Decerto que o conteúdo da postura estratégica brasileira, de duplo viés diplomático-militar, tem sido marcadamente diplomático, por causa da falta de vontade e de condições do país de assumir um papel expansionista e de exercer uma efetiva política de poder, contribuindo para a relativa tranquilidade bélica em todo continente americano.

A segunda razão está na dificuldade de como manter a soberania dentro de um quadro de constituição de blocos regionais e de globalização das decisões políticas e econômicas dos países que lideram a ordem internacional; mesmo porque no plano militar, não houve muita discussão sobre qualquer tipo de mecanismo de defesa regional e continental. Se para uma realidade de Terceiro Mundo isto se impõe de modo patente, mais ainda, ela se aprofunda no caso de um país que possui contradições internas e externas na projeção de sua influência no cenário internacional. Uma vez que o Brasil não pode 
explicitar e impor efetivamente uma ação de poder e força, ele buscou a saída para o prestígio e consideração da cooperação política regional e sub-regional por meio de seu poder brando e capital diplomático.

O legado desta questão se propagou nos governos do período democrático e continuou nos governos de Lula da Silva e Dilma Rousseff. Durante este tempo, o país continuou também travando uma batalha interna, pois necessitava investir maciçamente na melhoria da situação socioeconômica e nos índices de desenvolvimento. Assim, as possibilidades de atuação militar no cenário global continuam sendo um tanto reduzidas para o Brasil. Considerase igualmente que a vinculação entre a melhora da realidade socioeconômica e situação de paz continental está explicitada na sua política de defesa e na tradicional posição pacífica, o que é avaliado como sucesso da política externa brasileira, tal qual está expresso nos documentos oficiais de defesa e da diplomacia. Entretanto, esta postura não impediu que houvesse dificuldades geradas pela assimetria de poder político e econômico frente aos países desenvolvidos, pois, permaneceram também as tentativas de abordar os problemas comuns aos países sul-americanos no desenrolar do processo de cooperação. Isto pode ser observado, tanto no plano do desenvolvimento sustentável como na área de segurança internacional e defesa na sub-região, por exemplo, na situação da bacia amazônica (Silveira 2015).

Tais dificuldades referem-se ao contexto hemisférico e aquilo que $\mathrm{Bu}$ zan e Hansen (2012) chamaram de "política das grandes potências", sobretudo com o peso específico dos EUA nas relações internacionais. Como se sabe, as questões do comportamento dos Estados e das instituições no sistema internacional se preocupam, tradicionalmente, em estudar a guerra e outros fenômenos estabelecidos nas disputas interestatais, assim como a busca pela manutenção da paz e suas repercussões nas relações de conflito e cooperação (Halliday 1999). Neste caso, é importante considerar o conjunto das questões quer envolvem o Brasil e a América Latina, especificamente, a América do Sul, seja no relacionamento com seus parceiros globais, seja no contexto do passado presente da bipolaridade ou da atual dominância dos EUA. Esta aconteceu dentro de uma realidade onde se mantêm uma vertente unipolar e unilateral, construída a partir do estabelecimento de sua presença histórica no mundo ocidental, principalmente a partir do século XX, com o capitalismo liberal, o keynesianismo e a globalização neoliberal e do "turbocapitalismo" (Ayerbe 2007). Para este autor, tal isto foi instituído como resultado de um "destino manifesto" com o objetivo de promover um capitalismo democrático na então chamada Nova Ordem Internacional, visando a "ocidentalização" do mundo.

No passado recente, as estratégias empreendidas pela Doutrina Bush, a partir dos ataques terroristas de 2001, consolidaram atitudes de maior securitização das relações internacionais. Isto levou ao empreendimento de outras guerras e à mudança da estrutura interna da administração governamental dos EUA para agir a favor dos que estão com esse país e contra seus inimigos
Política de defesa, segurança internacional e Forças Armadas Brasileiras no contexto sub-regional

Cláudio de Carvalho Silveira 
(Pecequilo 2003). Desta maneira este país estabeleceu ações variadas para determinar que seu poderio em escala global fosse mantido, através da guerra contra o terror. Assim, a superpotência desenvolveu objetivos estabelecidos na National Homeland Security, em 2002 e na National Security Strategy of the USA, em 2006 para prevenir ataques minimizar danos e reduzir as vulnerabilidades do país, trazendo importante resultados para as ações militares e policiais em todos os quadrantes do planeta. Na percepção desta autora, os EUA não seriam exatamente um império, pois contou com resistências à sua dominação global e seu intuito de estabelecer uma "pax americana" em vários lugares do quadrante, promovendo um determinado estilo de vida, conforme já apontaram também Negri e Hardt (2000). Porém, seria impossível desconhecer atual poder daquele país de ditar normas da convivência internacional num ambiente que busca privilegiar os princípios do multilateralismo (Pecequillo 2008). Com tal situação, foi possível perceber que, no século XXI, se desenvolveu tanto uma militarização das ações de modo unipolar, como a construção das tentativas de organizar uma ordem multipolar com maior inserção dos países com as implicações da proeminência do capitalismo ocidental em seu comportamento e determinações sócio-políticas Estas, por sua vez, causaram sério impacto na realidade sul-americana de ordem políticoestratégica, condicionando sua modelagem defensiva.

A terceira razão refere-se à capacidade de resposta com a instituição de fundamentos balizadores da ação político-estratégica brasileira. Os documentos de defesa brasileiros contam com uma avaliação do panorama internacional (regional, sub-regional e mundial), levando em conta a situação do país em ambos os planos e adotando uma visão complexa do problema da segurança internacional, sem, contudo, incorporar o conceito de segurança cooperativa. Esta avaliação oficial assumiu dimensões econômicas, culturais e políticas, numa significação genérica e declaratória quanto ao envolvimento do Brasil na política internacional e o consequente preparo e emprego das suas FFAA de maneira prioritariamente dissuasória, conforme Nogueira (2007).

Neste sentido, percebe-se também que o Brasil e certo grupo de países do Sul, continuaram buscando espaços de inserção no sistema que constrói barreiras e possibilidades de modificar-se, ao buscar a preservação de suas características de um estado nacional afetado pela globalização na montagem das características de sua política de defesa frente aos demais estados (Vizentini 2003). Eles permanecem condicionados a uma nova agenda estabelecida pós-1989 cujos tópicos principais passaram a ser: abertura comercial, migrações, terrorismo, conflitos étnicos, delitos transnacionais, agressões ao meio ambiente, etc., definindo-se em novas ameaças, sem afastar de todo as ameaças tradicionais, no campo da segurança internacional e da defesa. Para tal, os governos sul-americanos, críticos do neoliberalismo liderados por Brasil, Argentina e Venezuela, propuseram aos demais países sul-americanos novos arranjos institucionais como a UNASUL e o CDS. Estas foram novas tentativas e implicações para estruturar os vínculos entre a política externa e de defesa 
nacionais a partir dos anos 1990 e 2000, sendo seguido nos posteriores, sem deixar de estender a abrangência da cooperação para além do subcontinente.

$\mathrm{O}$ desenrolar deste processo pode ser observado na realidade brasileira com a adoção de uma agenda mais abrangente no plano internacional. Ao longo do tempo, para cumprir este propósito, os governos civis brasileiros, ao seu modo, buscaram meios de integração sub-regional com prioridade na política externa e de defesa à América Latina especificamente, a do Sul, sem esquecer as ligações histórico-culturais e estratégicas com os EUA, a Europa, Ásia e Oriente Médio, além da África. No caso do continente africano, buscouse avançar nas ações diplomático-militares com maior integração, sobretudo a partir da tentativa de dinamizara Zona de Paz e Cooperação do Atlântico Sul (ZOPACAS) criada em 1986, fortalecendo alguns aspectos da relação Sul-Sul. Isto ocorreu a fim de construir um maior entendimento para a cooperação transatlântica, principalmente com uma "diplomacia cultural" países africanos da Comunidade de Países da Língua Portuguesa (CPLP) e a melhoria das relações com a África do Sul pós-regime "apartheid" e a busca de articulações negociadas no âmbito do G-20. Tais atos serviram, para estreitamento das parcerias com os países subdesenvolvidos e ações comuns Sul-Sul, diante da comunidade internacional, como a busca de reformulação do Conselho de Segurança das nações Unidas (CSNU) e o incremento das relações tecnológicas e comerciais. Contudo, a defesa ainda estava por merecer igual tratamento como tem sido dispensado nos empreendimentos dos planos comercial e cultural. Tentou-se modificar esta postura nos governos Lula e Dilma, com uma política externa chamada de "ativa e altiva" pelo ex-chanceler e ex-ministro da defesa Celso Amorim nas análises deste período, pois articulou novos temas e ações na agenda internacional (Amorim 2016). Este esforço de diversificação continuou na cooperação técnico-militar com Índia, China e Rússia no plano aeroespacial, para fugir da submissão político-estratégica do Ocidente e tentar diminuir o abismo tecnológico existente. Por esta razão, buscou-se estabelecer um diálogo cooperativo no campo da defesa que envolve a padronização e o reequipamento da máquina de guerra. Isto foi feito com a tipologia bélica da OTAN, especificamente com a influência das tecnologias alemã, inglesa e francesa, além da tradicional presença dos sistemas de armas e das doutrinas existentes nos EUA. Por outro lado, também se deu abertura às negociações para aquisição de material bélico de origem russa.

Apesar deste esforço de ampliação da cooperação nesses governos, podese ainda discutir que tipo de papéis o Brasil deve desempenhar na região: hesita como líder regional e se põe, interlocutor privilegiado no MERCOSUL, UNASUL e CELAC (Comunidade dos Estados Latino-Americanos e Caribenhos) possui acordos com os EUA, Europa, Ásia e África, ou poderia ainda ser visto como pretenso agente sub-imperialista das potências hegemônicas na sub-região sul-americana. Tentando superar tais deficiências, o Brasil se manteve na dinâmica de diálogo e manutenção da paz, por exemplo: a) atuações na consolidação da região amazônica através do TCA e, depois, da Organização do
Política de defesa, segurança internacional e Forças Armadas Brasileiras no contexto sub-regional

Cláudio de Carvalho Silveira 
Tratado de Cooperação Amazônica (OTCA); b) assinatura do TNP; c) busca pela revisão do TIAR.

Houve também debate sobre a participação no regime de tecnologias sensíveis, a revalorização da ZOPACAS, da participação em operações de paz da Organização das Nações Unidas (ONU) além da (re)consideração da OEA sobre multidimensionalidade da segurança internacional hemisférica.

Assim, nos parece válido afirmar que o país buscou razoável espaço de manobra, apesar das imposições hegemônicas dos EUA e seus aliados da OTAN (como a reorganização da IV Frota, a negociação do uso de bases militares em território sul-americano, a demanda crescente sobre o uso das FFAA sub-regionais para combate ao narcotráfico etc.) Por exemplo, este espaço buscou se materializar na cooperação com os países do boco BRIC, apesar de sua heterogeneidade; outro exemplo foi a proposta de criação do CDS, superando possíveis resistências e suspeitas apresentadas pelos países da América do Sul.

\section{Alguns projetos de modernização militar brasileira atual}

Com este contexto em curso, o Brasil se pôs a pensar nas orientações estabelecidas pelas políticas de defesa dos países envolvidos, bem como a materialização de sua máquina militar, nos termos de equipamentos e capacidade operacional. Esta atitude continuou condicionada pelo orçamento destinado à defesa nacional em relação ao PIB e aos demais gastos das rubricas estabelecidas em outras políticas públicas não se caracterizando como uma "corrida armamentista" diante da opinião pública internacional (Caamaño 2010). Como afirmou este autor, apesar de modernizar seus meios militares, o Brasil não possui automaticamente a melhor máquina do subcontinente só por ser o maior dentre os seus países. Aqui haveria de se levar em conta os planos de reequipamento de países como Colômbia, Peru, e Venezuela, por exemplo. Além disso, há o Chile que, como decorrência da Lei do Cobre, possui as FFAA que são consideradas das mais atualizadas da América do Sul. O Brasil pretendeu dar um salto qualitativo com os programas mencionados a seguir para sair do sucateamento e chegar a um nível crível de capacidade dissuasória contra outras potências, sobretudo extra-regionais, que viessem representar algum tipo de ameaça contundente ao país. Por isso, a nova exigência legal da compra de produtos com transferência do conteúdo tecnológico pode dotar o país de melhores condições para que isso se efetive. Tal procedimento brasileiro, a partir de Lula da Silva, buscou vincular a defesa com o desenvolvimento nacional, dando incentivos e criando uma lei especial para que o mercado de defesa pudesse crescer buscando o setor interno e externo.

Nosso entendimento é o de que este fator permanece significativo para pensar não só a modernização técnico-operacional, mas, também, as relações civis-militares e o processo de democratização latino-americana. Isto porque 
houve o incremento das atividades de polícias especializadas e das determinações estadunidenses na América do Sul, contribuindo para o aumento de sua influência no subcontinente com o Plano Colômbia. O governo colombiano concordou com o objetivo da ação preconizada na administração Clinton e implementado por seus sucessores na presidência dos EUA, o que rendeu vários tipos de análises sobre as pretensões de Washington. Tal fato tem sido, até hoje, argumento para muitos criticarem os custos e a importância das missões precípuas de defesa empreendidas pelas FFAA brasileiras em detrimento do desenvolvimento econômico e a segurança pública e o saneamento dos problemas de desigualdade social. Isto tem sido motivo para propostas que pretendem levar à diminuição dos gastos com defesa e à da análise sobre a distribuição dos mesmos, embora se demonstre que a maior parte dos recursos tenha a ver com as despesas voltadas ao pagamento de pessoal, restando relativamente pouco para a pesquisa e o reaparelhamento militar (Aguilar 2007). Para rebater o argumento de que as FFAA são desnecessárias à defesa nacional e justificar que o país necessita delas, além dos documentos elaborados pelo governo, procurou-se chegar à cifra de $2 \%$ do PIB nacional, como meta dos gastos de defesa no país.

Há que considerar ainda que foi uma boa novidade quando desde 2005 a 2012, houve apresentação e atualização dos documentos referentes à defesa. Entretanto, tal atitude ficou aquém das expectativas porque a elaboração desses documentos, ainda se restringe a um seleto e pequeno número de militares, burocratas, acadêmicos, políticos, formando um grupo de notáveis, portanto, com pouca participação efetiva da sociedade, como em outas políticas públicas, como, por exemplo, a END. Destacamos este aspecto porque, em nossa percepção, a despeito da propalada situação de tranquilidade e pacifismo é necessário que a sociedade brasileira se envolva com o tema por ser de interesse básico para todos os seus membros, levando aos cidadãos ao envolvimento com este tipo de assunto. Neste documento, a preocupação brasileira é a de que a defesa seja definitivamente posta na agenda nacional, deixando de ser apenas uma área de saber técnico-profissional de todos militares e poucos civis. Através de seus representantes políticos e administrativos, especialistas e acadêmicos, os cidadãos poderão contribuir para aperfeiçoar os princípios estabelecidos na END que está estruturado em três eixos: a) reorganização das FFAA; b) reorganização da indústria brasileira de material de defesa e c) política de composição dos efetivos das FFAA. Em seu texto se estabeleceram as diretrizes estratégicas para as FFAA e o seu papel nos setores cibernético, espacial e nuclear, com o incremento paulatino de tecnologia nacional. O plano também ressalta a importância da composição do efetivo militar profissional e do serviço militar obrigatório, a fim de que haja maior representatividade de todas as classes sociais, pondo a nação acima delas, segundo certo ideal republicano (Ministério da Defesa 2012).

Entendemos também que uma das questões mais importantes para o debate sobre a (in) conveniência da adoção do conceito de segurança cooperativa
Política de defesa, segurança internacional e Forças Armadas Brasileiras no contexto sub-regional

Cláudio de Carvalho Silveira 
é a valorização deste princípio conjugado à modernização das FFAA brasileiras. Por exemplo, no contexto amazônico, principalmente, após a criação do TCA e a OTCA, o Brasil procurou estabelecer cooperação e integração com seus vizinhos para melhor proteger a região de problemas decorrentes das novas ameaças ligados aos ilícitos transnacionais (Vargas 2010). Além disso, a existência de grupos políticos armados ofereceu mais argumentos para que o Brasil fortalecesse o Sistema de Vigilância da Amazônia (SIVAM) / Sistema de Proteção da Amazônia (SIPAM) e uma série de ações e iniciativas governamentais para minimizar conflitos com a Colômbia, Venezuela e o Suriname. Isto aconteceu ainda mais num momento onde a Amazônia foi vista como um alvo da cobiça e atenção internacional, por causa de suas riquezas naturais. Como já dito, outro fator relevante foi a implementação do Plano Colômbia, fonte de questionamentos de alguns países sul-americanos, por aumentar a influência dos EUA na sub-região. Pensando nisso, o Brasil desenvolveu também operações de treinamento militar com a Colômbia (COBRA), Peru, Venezuela (VENBRAS e CRUZEX) com o Suriname. Elas têm sido feitas a partir dos anos 1990 para articular melhor a prevenção de potenciais conflitos entre atores estatais e não estatais, mesmo não se enquadrando na moldura de segurança cooperativa aludida anteriormente.

Há outros exemplos de modernização militar que podem fomentar as expectativas de cooperação no plano técnico-operacional estão nos principais programas de reaparelhamento seguindo o que a PND/END determinam desde 2005 e 2008, respectivamente, sem causar oposição dos países sul-americanos. Eles estão distribuídos e razoavelmente equilibrados entre as três FFAA, para viabilizar o Plano de Articulação de Equipamento de Defesa (PAED) e a Base Industrial de Defesa (BID), conforme veremos a seguir. A decisão brasileira de reforçar a sua capacidade de projeção militar na área levou à criação de programas de reaparelhamento naval. Estes programas têm sido um fator de modernização, visando que a Marinha passe a um patamar mais elevado de capacidade dissuasória, por meio do intercâmbio feito com outras marinhas, como as de países europeus (Silveira 2001). Tais programas são: a) PROSUB (Programa de Construção de Submarinos) cujo destaque é a construção de submarinos com propulsão nuclear; b) Programa do Navio Aeródromo (PRONAE); c) Programa de Construção de Navio Anfíbio (PRONAG) e d) Programa de Construção de Navios de Superfície (PROSUPER), como novos barcos-patrulha e corvetas da classe Barroso. É necessário dizer ainda que a Marinha é responsável pela viabilidade do Sistema de Gerenciamento da Amazônia Azul (SISGAaZ), que junta recursos e compartilha informações com outras Forças, para vigiar e proteger o mar brasileiro. Para a defesa aérea a Força Aérea Brasileira (FAB), adquiriu 36 caças Grippen da Suécia e comprou outra categoria de aviões Super Tucano e o cargueiro KC-390 da Embraer. O país tem melhorado também os equipamentos do Exército Brasileiro (EB), com um novo programa de aquisição de blindados, artilharia antiaérea, helicópteros e a instalação do Sistema de Monitoramento de Fronteiras (SISFRON), valorizando o uso de sofisticação 
tecnológica inédita para a proteção das fronteiras s u 1 e oeste do país, o que também envolve estrita cooperação de vizinhos como a Argentina, o Uruguai e o Paraguai, dentre outros vizinhos. Devemos ressaltar que esta modernização militar brasileira não tem sido vista de maneira negativa, segundo o discurso oficial elaborado por seus vizinhos do sul e latino-americanos , tampouco pelos países africanos, como os da ZOPACAS, pois, ela ajuda na criação de melhores mecanismos de defesa, permitindo que estes países usufruam dessa realidade como: melhoria da profissionalização militar, intercâmbio econômico da indústria de defesa e seus serviços entre si e suas respectivas sociedades. Tal procedimento reflete a necessidade da criação de instrumentos mais robustos de defesa, capazes de permitir vencer as ameaças e tratar de superar as suas vulnerabilidades e possíveis ameaças no Atlântico Sul com a atuação do Brasil e seus vizinhos (Silveira 2014).

Existem outros exemplos de projetos que promotores de mudanças organizacionais que significam modernização das FFAA, relacionados à formação e ao critério de ingresso e desenvolvimento na carreira. Por exemplo, a introdução de mulheres nas profissões da linha bélica e a criação de novos cursos de treinamento e aperfeiçoamento, tanto na educação para o combate quanto nas áreas de apoio nos cursos de nível secundário e universitário de graduação e pós-graduação nos mais altos níveis. Tais iniciativas visam capacitar militares e civis para o planejamento administração em defesa, que é uma demanda governamental. Entretanto, a nosso ver tais práticas serviram muito mais para aumentar as perspectivas autonomia político-institucional das FFAA, deixando de lado a necessária expansão da discussão, análise sobre a formação de civis militares em defesa e segurança internacional, no âmbito das universidades civis. Ao contrário do que se poderia esperar da eficácia do controle civil sobre os militares, criou-se um novo modo de influência das FFAA ao buscar competir e suplantar as instituições produtoras e reprodutoras de conhecimento sobre a política de defesa. Houve autorização do governo para esses projetos, de acordo com os documentos oficiais da arquitetura de defesa nacional, inclusive, com o reconhecimento do Ministério da Educação (MEC). Por isso a Marinha, Exército e a Força Aérea criaram, respectivamente, cursos de mestrado profissional, mestrado acadêmico e doutorado, conquistando uma significativa posição na disputa por recursos, prestígio e poder na fronteira do conhecimento com as instituições civis. Entretanto, neste aspecto entendemos que o melhor caminho adotado não seria este, pois torna as FFAA mais encapsuladas e possuidoras de mais prerrogativas em relação às instituições civis, na área de ensino profissional. Nossa percepção é a de que isto contribui para aumentar seu corporativismo, distanciar a execução da política de defesa da supremacia civil e comprometer a melhoria da democracia brasileira, ainda que formalmente, se possa dizer o contrário, a fim de justificar a promoção de maior intercâmbio com as instituições civis (Silveira 2016).

Por fim, tem havido cooperação e modernização militar no campo das operações de paz. O Brasil participou dos mandatos onusianos no Haiti,
Política de defesa, segurança internacional e Forças Armadas Brasileiras no contexto sub-regional

Cláudio de Carvalho Silveira 
Líbano, Chipre, Saara Ocidental, Sudão, Sudão do Sul, República Democrática do Congo, Libéria e Costa do Marfim. Como já noticiado, o Brasil está saindo da MINUSTAH (Jornal do Brasil, 2 de junho de 2017), depois de proclamar uma oportunidade ímpar de tentar ajudar a construir um novo paradigma de operações de paz. Ao lado de diversos países, dentre os quais, seus parceiros da América do Sul, como Chile, Argentina e Uruguai vê sua atuação no Haiti como próxima do fim. Em 2004, nosso país aceitou iniciar tal participação em nome da solidariedade internacional, possibilidade de projeção brasileira no mundo, da herança étnico-cultural comum, segundo Amorim (2016). Isto contribuiu para reforçar a venda de sua imagem de país pacifista e ajudador de seus parceiros latino-americanos na causa do desenvolvimento e diminuição das mazelas sociais, contribuindo para legitimação de seu pleito de reforma e participação permanente no CSNU. Naquela ocasião, houve certa polêmica entre autoridades brasileiras e internacionais, pois, o Brasil não pretendia participar de operações baseadas no Capítulo VII (imposição da paz) da Carta das Nações Unidas, apenas do Capítulo VI (manutenção da paz). Apesar disso, teve que cumprir o mandato de imposição da paz, preconizado no Capítulo VII por razões político-institucionais. Para tentar diminuir a polêmica, uma saída foi dizer para a opinião pública interna que esta seria uma boa ocasião para treinar os militares das FFAA para apoiar o Haiti no seu processo de pacificação interna, sendo a mesma um aprendizado para atuarem no Brasil para cumprirem tarefas subsidiárias de Garantia da Lei e da Ordem (GLO), combate ao crime organizado e ao narcotráfico nas fronteiras e cidades do país. Apesar desta atitude, como lembrou a análise de Correa (2014), as tropas de vários países, inclusive as brasileiras, junto com a Polícia Nacional Haitiana $(\mathrm{PNH})$, foram criticadas pelas ONGs e população haitiana, por cometerem violações variadas de direitos humanos.

Mesmo que não houvesse estes tipos de problemas sobre as missões de paz, a utilização das FFAA para combater o narcotráfico e outros ilícitos em território nacional, em apoio ou substituição das polícias dos estados brasileiros é um assunto bastante controverso. Há uma parte da sociedade que apoia estas ações por motivos variados, tais como: ineficiência das polícias, conveniências político-eleitorais, imprecisão constitucional, boa imagem dos militares na sociedade, tradição intervencionista e salvacionista das FFAA latino-americanas, interesses das grandes potências, especialmente dos EUA, similaridade da experiência de outros países latino-americanos, etc.

Não obstante estas posições, nosso entendimento é contrário ao uso de todas estas justificativas de uso das FFAA como agentes de segurança pública. Para nós, os militares deveriam ser usados apenas em conflitos internacionais e missões externas, com exceção de atividades eminentemente humanitárias, no plano interno. A decisão mais adequada para ajudar a resolver crises de segurança pública, o país deveria criar uma guarda nacional permanente e treinada com este fim, para ajudar as polícias estaduais e federais (Silveira 2012). 


\section{Considerações finais}

Procuramos aqui destacar nos tópicos anteriores algumas das principais questões no âmbito da formulação e da materialidade das políticas de defesa dos Estados e suas doutrinas estratégicas. Daí, enfatizamos a situação atual, na qual buscamos apresentar a discussão sobre os fundamentos da constituição dos Estados contemporâneos ao longo da história do século XX e XXI. Aqui também consideramos a organização da missão, preparo e emprego de suas FFAA no plano político interno e externo e os objetivos que os determinam em países como os da América Latina, especialmente a realidade da América do Sul e seus espaços. Enfatizamos a possibilidade do Brasil de ter uma visão e prática de segurança cooperativa conjugado à manutenção de certo tipo de liderança regional, ainda que o mesmo possa ser considerado questionável e hesitante.

Em função da presença brasileira no plano internacional no passado recente, entendemos que a elaboração de um conjunto de documentos oficiais tão ampliados e importantes como a PND e a END e o LBDN, que foram constituídos a partir dos anos 1990 até os anos 2000, nos leva a considerar a validade de seus objetivos e questões e inquietações, juntamente com as análises acadêmicas sobre o tema aqui apresentadas. Entendemos que isto pode ser continuamente aprofundado através da pesquisa na área da defesa aqui proposta para auxiliar na análise das questões no campo das relações internacionais, conforme estipulamos a seguir.

Num plano mais generalizado, com as diferenças de interesses, níveis e significados de cooperação, foi necessário apresentar determinados aspectos sobre a modernização militar brasileira em suas vertentes organizacional e técnico-operacional da profissão castrense. E, ainda ressaltar a institucionalidade do MD, do CDS da UNASUL e a maneira como eles podem ajudar a construir mecanismos que facilitem a cooperação e a integração das FFAA sul-americanas, sobretudo os interesses comuns e promover a paz no contexto regional. Neste sentido, admitimos que há desafios que devem ser considerados no que diz respeito aos seus projetos de força e as dificuldades para a cooperação e a integração dos países-membros envolvidos no processo de sua materialidade.

Ademais, consideramos a necessidade de adaptação do Brasil a um novo contexto internacional mundial e regional e sub-regional, atentando para os fundamentos da missão, preparo e emprego das FFAA como política pública de defesa concebida ao lado da condução da política externa. Passou a existir um conjunto maior de atores internos (militares, acadêmicos, diplomatas, jornalistas, etc.) e externos (Estados, organismos internacionais atuantes nas áreas de segurança e defesa) que se fizeram e se têm feito presentes no contexto da elaboração e prática dessas políticas, principalmente, a partir da criação do MD e seu desenvolvimento institucional, feito por meio dos documentos oficiais norteadores da defesa nacional. Esta decisão governamental
Política de defesa, segurança internacional e Forças Armadas Brasileiras no contexto sub-regional

Cláudio de Carvalho Silveira 
procurou promover uma articulação melhor com o MRE e outros ministérios afins, quando necessário, para viabilizar maior segurança sub-regional e propor um caminho para articular melhor os princípios de cooperação. Neste caso, nossa percepção é a de que o Brasil não precisaria abrir mão do conceito de segurança cooperativa, seguindo o exemplo da Argentina e do Uruguai, mesmo entendendo que sua origem remonta à iniciativa hegemônica feita pelos EUA ao disseminá-lo de acordo com seus interesses nacionais e hemisféricos. Porém, avaliamos que esta não é a postura adotada pelo país, ainda que promova ações de cooperação com seus parceiros dentro e fora do seu entorno estratégico.

Com isto em perspectiva destacamos, então, alguns tópicos referentes à modernização do emprego político militar em relação à política externa brasileira na sua estrutura de forças no uso da Marinha, Exército e Aeronáutica. Ou seja, enfatizamos a melhoria da qualidade do poder militar brasileiro e o contexto de sua inserção histórico-política no plano sub-regional, regional e mundial desde o fim dos governos militares até os dois mandatos de Dilma Rousseff que criaram ações neste campo.

Em nossa percepção, sobretudo ao longo dos governos civis pós-ditadura militar até a crise de 2016, o cenário de segurança sub-regional atual levou à consideração a criação de instrumentos regionais de cooperação política que implica na modernização das suas FFAA. Eles foram refletindo determinadas formas as dinâmicas de reaparelhamento das forças militares da América do Sul e a reorientação estratégica dos países se desenvolveu, e continuam se desenvolvendo em curto e médio prazo, de forma a permitir uma conciliação com o desenvolvimento de um ambiente político regional cooperativo, marcado pelo surgimento da UNASUL e, em especial, pelo CDS. O Brasil continuou a investir numa perspectiva de ação multilateral para estabelecer as condições para a manutenção da paz no âmbito regional e sub-regional. Isto se deu, notadamente, no que lhe concerne no contexto do MERCOSUL, ZOPACAS e da UNASUL e procurou modernizar seu aparato militar em consonância com a percepção de seus vizinhos, ainda que vários passos pudessem ser dados para a sua efetivação.

Pretendemos destacar também que houve maior interdependência político-estratégica na América do Sul, a partir da participação desses atores estatais e não estatais, através dos processos de negociação para construir os mecanismos de cooperação e integração na área de defesa e política externa a fim de se manter a paz, configurando um complexo regional de segurança. Tal atitude não implica descartar que no futuro haja eventuais conflitos, advindos de alguma crise nesses países, que podem resultar em riscos, ameaças e vulnerabilidades, resultantes de problemas internos à sub-região ou interferência das grandes potências.

Percebemos que, nesse período, houve importante tentativa de conciliação entre a política de cooperação em defesa, com fatores da modernização militar, por causa de características dos dois aspectos adotados entre os países sul-ame- 
ricanos envolvidos. Tal coexistência foi possível por que o modelo de cooperação política construído não pretendeu excluir de sua efetivação, o aperfeiçoamento da organização militar dos países, pelo contrário, pode incentivá-lo.

Enfim, avaliamos também que o mesmo desenvolvimento militar não foi efetuado de forma a ameaçar países fronteiriços, regionais, processando-se de forma defensiva, não ofensiva e visando cooperar com o tão almejado desenvolvimento social / bem-estar de cada país. Esta situação permitiu atestar a existência de características que diferenciam este contexto estratégico-militar regional que passou a existir sob a influência da governabilidade democrática e do crescimento de uma maior consciência acerca da realidade sul-americana. Esta é uma questão importante para saber se tal atitude pode contribuir para a construção de uma possível identidade sub-regional com base em novos mecanismos de cooperação, como possibilidades de se desenvolver e consolidar.

\section{Referências bibliográficas}

Amorim C. (2016), A grande estratégia do Brasil: discursos, artigos e entrevistas da gestão no Ministério da Defesa (2011-2014), Editora UNESP, São Paulo.

Alsina J. P. JR (2009), O poder militar como instrumento de política externa, "Revista Brasileira de Política Internacional", ano 52, no 2, pp. 173-191.

Aguilar S. L. (2007), Políticas de defesa e orçamentos militares no Cone Sul, em: Defesa, Segurança Internacional e FFAA, I Encontro da ABED, M. C. D'Araujo, S. Soares, S. K. Mathias (eds.), Mercado de Letras, Campinas.

Ayerbe L. (2004), Dimensões histórico-culturais da ordem internacional: A América Latina e a "ocidentalização" do mundo, em: Ensaios Latino-Americanos de Política Internacional, R. D. Villa, S. K. Mathias (eds.) Hucitec, São Paulo.

Bandeira L. A. M. (2009), Geopolítica e política exterior: Estados Unidos, Brasil e América do Sul, FUNAG, Brasília.

Buzan B., Hansen L. (2012), A evolução dos estudos de segurança internacional, São Paulo, Editora UNESP.

Buzan B., Weaver O., de Wilde J. (1998), Security: A New Framework for Analysis, Lynne Rienner, London.

Caamaño L. (2010), Conflictos regionales y armamentismo en América Latina, em: Luces $y$ sombras de la seguridad internacional en los albores del siglo XXI, Tomo II, M. Requeña, (ed.) IUGM- UNED, Madrid.

Cervo A. (2008), Inserção internacional: formação dos conceitos brasileiros, Saraiva, São Paulo.

Correa P. G. (2014), MINUSTAH e diplomacia solidária: criação de um novo paradigma? em: Haiti: Segurança ou desenvolvimento no início dos anos 1990, V. B. Matijascic (ed.), Editora Appris, Curitiba.

Dreifuss R. A. (1993), O mar e a marinha no contexto das tendências de estruturação do novo cenário mundial, "Premissas", cad. 4, agosto 1993, pp. 50-66.

Diamint R. (2001), Democracia y seguridad en América Latina, Nuevohacer \& Universidad Torquato di Tella, Buenos Aires.
Política de defesa, segurança internacional e Forças Armadas Brasileiras no contexto sub-regional

Cláudio de Carvalho Silveira 
Freixo A., Rodrigues T. (2016), Introdução: Sobre crises e golpes ou uma explicação para Alice, em: 2016, o ano do golpe, A. Freixo, T. Rodrigues (eds.), Oficina Raquel, Rio de Janeiro.

Fuccille L. A. (2015), Apontamentos para pensar a segurança na América do Sul no século XXI, em: Perspectivas e debates em segurança, defesa e relações internacionais, D. Chavez, E. Winand, L. Pinheiro (eds.), Editora UNIFAP, Macapá, Autografia, Rio de Janeiro.

Giddens A. (2001), O Estado-nação e a violência, EDUSP, São Paulo.

Gonçalves W. da S., Miyamoto S., (2000), Militares, diplomatas e política externa no Brasil pós-64, em: Sessenta anos de política externa: Prioridades, atores e políticas, J. A. Albuquerque (ed.), EDUSP, São Paulo.

Halliday F. (1999), Repensando as relações internacionais, Editora UFRGS, Porto Alegre.

Jornal do Brasil, Brasil envia última tropa para missão de paz no Haiti http://www.jb.com. br/internacional/noticias/2017/06/02/brasil-envia-ultima-tropa-para-missao-de-paz-nohaiti/. Consulta em 03.06. 2017.

Keohane R. (1992), Soberania estatal e instituições multilaterais: respostas à interdependência assimétrica, em: O futuro do Brasil: A América Latina e o fim da Guerra Fria, J. A. Moisés (ed.), Paz e Terra, Rio de Janeiro, EDUSP, São Paulo.

Lima M. R. S. de (2010), Diplomacia, defesa e a definição política dos objetivos internacionais: O caso brasileiro, em: Segurança internacional: Perspectivas brasileiras, N. Jobim, S. Etchegoyen, J. P. Alsina JR (eds.), FGV, Rio de Janeiro.

Lora M. (2010), Seguridad cooperativa en América Latina, em: Luces y sombras de la seguridad internacional en los albores del siglo XXI, Tomo II, M. Requeña (ed.), IUGMUNED, Madrid.

Mann M. (1992), O poder autônomo dos Estados: Suas origens, mecanismos e resultados, em: Os Estados na história, J. Hall (ed.), Imago, Rio de Janeiro.

Ministério da Defesa (2012), Política Nacional de Defesa \& Estratégia Nacional de Defesa, http://www.defesa.gov.br/arquivos/estado_e_defesa/END-PND_Optimized.pdf. Consulta em 18.12.2015.

Ministerio de Defensa Argentino (2014), Informe: Política Nacional de Defensa, disponível em: www.mindef.gov.ar. Consulta em 15.10.2014.

Ministerio de Defensa (2005), La Defensa nacional. Aportes para un debate. Consulta em 31.10.2014.

Negri A., Hardt M. (2000), Empire, Paris, Exils.

Nogueira M. A. (2007), Dissuasão e coerção: o emprego da força pelo Estado, em: Defesa, segurança internacional e FFAA, I Encontro da ABED, M. C. D’Araújo, S. A. Soares, S. K. Mathias (eds.), Mercado de Letras, Campinas.

Pecequilo C. S. (2003), As faces e consequências do terror: de 11/09 à Doutrina Bush, "Idéias", ano 10(2), pp. 55-82.

Pecequilo C. S. (2008), A política externa do Brasil no século XXI: Os eixos combinados de cooperação horizontal e vertical, "Revista Brasileira de Política Internacional", ano 51, no 2, 2008, pp. 136-153.

Ramonet I. (1998), Geopolítica do caos, Vozes, Petrópolis.

Rouquié A. (1984), O Estado militar na América Latina, Alfa-Ômega, São Paulo. 
Saint-Pierre H. L., Winand E., Pereira C. J. (2004), Compassos e descompassos da cooperação em segurança entre Brasil e Argentina, em: Ensaios latino-americanos de política internacional, R. D. illa, S. K. Mathias (eds), Hucitec, São Paulo.

Schultz D. (1999), The Role of the Armed Forces in the Americas: Civil Military Relations for the $21^{\text {st }}$ Century, Institute for National Strategic Studies, Washington D. C.

Silva G. do C. e (1981), Conjuntura nacional, o poder executivo \& geopolítica do Brasil, José Olympio Editora, Rio de Janeiro.

Silveira C. de C. (2016), A formação dos oficiais da Marinha do Brasil: educação, profissão, pensamento estratégico (1978-2001), Novas Edições Acadêmicas, Saarbrücken.

Silveira C. de C. (2015), A presença da Marinha do Brasil na Amazônia, "Paiaguás: Revista de Estudos sobre a Amazônia e o Pacífico" vol. 1, no 1, fevereiro-julho de 2015, pp. 82-101.

Silveira C. de C. (2012), Derechos humanos y violencia en Rio de Janeiro: ¿para qué sirven los militares? em: Gobernabilidad y democracia: defensa y transiciones de Brasil y España, S. Alda, H. L. Saint-Pierre (eds.), RIL Editores, Santiago de Chile.

Silveira C. de C. (2011), Política internacional e cultura de defesa na Marinha do Brasil e na Armada Espanhola, "Mural Internacional", ano II, no 1 junho de 2011, pp. 49-56.

Silveira C. de C. (2016b), Construção da identidade e educação militar brasileira no início do século XXI, em: Militares e democracia: estudos sobre identidade militar, S. K. Mathias, D. Zirker (eds.), Cultura Acadêmica, IPRI-UNESP, São Paulo.

Silveira C. (2014) Visões sobre o Atlântico Sul e a presença da Marinha do Brasil na Antártida, "Revista Brasileira de Estudos Estratégicos", Instituto de Estudos Estratégico da Universidade Federal Fluminense, Ed. no 4, vol. I, pp. 339-358.

Soares T. (1972) História da formação das fronteiras do Brasil, Biblioteca do Exército, Rio de Janeiro.

Soares S. (2012) Las percepciones sobre amenazas y cooperación en las políticas de defensa de Argentina, Brasil y Chile, em: Gobernabilidad y democracia: defensa y transiciones de Brasil y España, S. Alda, H. L. Saint-Pierre (eds), RIL Editores, Santiago de Chile.

Tokatlian J. G. (2002) Colômbia: Mais insegurança humana, menos segurança regional, “Contexto Internacional", vol. 24, no 1, janeiro/junho, pp. 129-166.

Tulchin J., Bitencourt L. (2005) Mercosur and the Creation of the Free Trade Area of the Americas, Woodrow Wilson Center for Scholars, Washington D.C.

Vargas A. (2010) Introducción, em: Inseguridad en la región amazónica: Contexto, amenazas y perspectivas, A. Vargas (ed.) Universidad Nacional de Colombia, Bogotá.

Vizentini P. (2003) Política de defesa e segurança do Brasil para o século XXI: soberania, questão amazônica e integração sul-americana, em: Política de defesa para o século XXI, A. Rebelo, L. Fernandes, Câmara dos Deputados, Brasília.

Vidigal A. A. (1996) O emprego do poder naval no limiar do século XXI, "Premissas", caderno 12, abril de 1996, pp. 33-78.

Waltz K. (1959) El hombre, el Estado y la guerra, Editorial Nova, Buenos Aires.

Tilly C. (1996) Coerção, capital e Estados europeus, EDUSP, São Paulo.
Política de defesa, segurança internacional e Forças Armadas Brasileiras no contexto sub-regional

Cláudio de Carvalho Silveira 